\title{
Effect of Demonstration Method of Teaching on Students' Achievement in Agricultural Science
}

\author{
Daluba, Noah Ekeyi ${ }^{1, *}$ \\ ${ }^{1}$ Department of Vocational and Technical Education, Kogi State University, Anyigba, Nigeria \\ *Correspondence: Department of Vocational and Technical Education, Kogi State University, Anyigba, Nigeria. \\ Tel: 234-806-671-6126.E-mail: sirdalus@yahoo.com
}

$\begin{array}{ll}\text { Received: October 4, } 2013 & \text { Accepted: November 4, } 2013 \quad \text { Online Published: November 12, } 2013 \\ \text { doi:10.5430/wje.v3n6p1 } & \text { URL: http://dx.doi.org/10.5430/wje.v3n6p1 }\end{array}$

\begin{abstract}
The study investigated the effect of demonstration method of teaching on students' achievement in agricultural science in secondary school in Kogi East Education Zone of Kogi State. Two research questions and one hypothesis guided the study. The study employed a quasi-experimental research design. The population for the study was 18225 senior secondary two (SSII) students in 195 secondary schools. Six (6) secondary schools were used for the study using purposive random sampling technique. In each of the school selected, two intact classes of the SSII were used. Four hundred and eighty (480) students in the twelve intact classes constituted the sample for the study. The instrument for data collection was a 30-item 'Agricultural Science Achievement Test' (ASAT). Using Kuder Richardson 20 (K-R20) formula, a reliability index of 0.78 was obtained. Research questions 1 and 2 and the only hypothesis were answered using mean, standard deviation and analysis of covariance (ANCOVA) at 0.05 level of significance. The result of study revealed that demonstration method had significant effect on students' achievement than those taught with the conventional lecture method. Useful recommendations such as: efforts should be made by teachers to thoroughly integrating demonstration method in the teaching of agricultural science in secondary schools; efforts should be intensified by teachers to aggressively adopt demonstration method in teaching agricultural science in all classes at the secondary school level were proffered.
\end{abstract}

Keywords: effect; demonstration method: teaching; students' achievement

\section{Introduction}

Agricultural Science is one of the core subjects taught in both junior and senior secondary schools in Nigeria. Because of its promising role in promoting self reliance through the provision of employment opportunities and production of staple foods for the populace together with raw material supply for the agro-allied industries, its teaching as a course offering in our schools and colleges has been made compulsory by the federal government.

The Federal Republic of Nigeria in its attempt towards the attainment of these laudable goals outlined the basic objectives of teaching agricultural science at the secondary school level as follows:

- $\quad$ To stimulate and sustain students interest in agriculture.

- $\quad$ To inculcate in students farming skills

- $\quad$ To enable students acquire basic knowledge and practical skills in agriculture.

- $\quad$ To prepare students for future studies in agriculture and

- $\quad$ To produce prospective future farmers (FRN, 2009:28).

The above objectives can only be attainable through effective instruction and motivation of students by teachers of agriculture. Surprisingly, most teachers of agricultural science in our secondary schools today are still known to have difficulty in teaching some agricultural science concepts thus leading to students' poor performance in such areas especially in prescribed external examinations like West African Senior Secondary School Certificate Examination 
(WASSCE), National Examination Council (NECO) and National Technical Education Board (NATEB) (Egun, 2007).

Again, there has been a general perception of agricultural science by an average Nigerian student, that it is a course that is dominated with practical and is majorly meant for students that are intellectually incapacitated (Adah, 2011). The way and manner students perceived the course, arises from the fact that instructional approaches adopted by teachers both in the classroom and on the field during teaching and learning process are not impressive. The effect of this is lack of interest and poor performance of students in the course. To arrest students' attention, interest, curiosity and promote their performance, the use of activity stimulating and student-centered approach like demonstration method instead of depending on the conventional approach need to be embraced.

Demonstration method refers to the type of teaching method in which the teacher is the principal actor while the learners watch with the intention to act later. Here the teacher does whatever the learners are expected to do at the end of the lesson by showing them how to do it and explaining the step-by-step process to them (Ameh, Daniel and Akus, 2007). Mundi (2006), described it as a display or an exhibition usually done by the teacher while the students watch with keen interest. He further added that, it involves showing how something works or the steps involved in the process. Some of the advantages of this method as outlined by Olaitan (1984) and Mundi (2006) include: - It saves time and facilitate material economy; the method is an attention inducer and a powerful motivator in lesson delivery; students receive feedback immediately through their own products; it gives a real-life situation of course of study as students acquire skills in real-life situations using tools and materials; it help to motivate students when carried out by skilled teachers and it is good in showing the appropriate ways of doing things.

Conventional lecture method is a common strategy teachers employ in the teaching of agricultural science. It is also referred to as talk and chalk or textbook method (Gbamaja, 1991). In the course of employing the method, the teacher dominates the teaching with very little participation on the part of the learners. Here the teacher is seen as the repository of all knowledge while the students are passive recipients of knowledge transmitted by the teachers in the process of learning. The method has the advantage of covering a wider area within a short time but it is not student centered and students do not gain mastery of concepts.

Having critically examined these two methods of teaching, the question now is what is the comparative effect of demonstration and conventional lecture methods of teaching on students' academic achievement in agricultural science in secondary schools in Kogi East Education zone of Kogi State, Nigeria?

\section{Purpose of the Study}

The purpose of the study was to determine the effect of demonstration and conventional lecture method on students' achievement in agricultural science in Kogi East Education zone of Kogi State, Nigeria. Specifically, the study sought to:

1. determine the achievement scores of students taught agricultural science with demonstration and conventional lecture methods.

2. determine the academic achievement scores of male and female students in agricultural science when taught with demonstration and conventional lecture methods.

\section{Research Questions}

The following research questions were formulated based on the purpose of the study:

1. Is there any significant difference in the mean achievement score of students taught agricultural science using demonstration and conventional lecture methods?

2. Is there any difference in the mean academic achievement scores of male and female students taught Agricultural Science with demonstration and conventional lecture methods?

\section{Hypothesis}

One null hypothesis is formulated at 0.05 level of significance as follows:

There is no significant difference in the Agricultural Science achievement scores between students taught with demonstration method and those taught with conventional lecture method. 


\section{Research Method}

The design of the study is a pre-test, post-test control group quasi experimental type. The pretest was used to establish equality or no difference between the treatment groups at the beginning of the experiment only.

The population of the study comprised of 195 secondary schools in the zone with 18,225 students. The sample consisted of six secondary schools of 480 senior secondary two (SSII) students drawn from the six secondary schools using purposive sampling technique. SSII students were selected for the study. The reason was because, the SSII class was not preparing for any external examinations unlike JSS III and SSIII classes. SSII students had completed SSI work in Agricultural Science and they were likely to be doing so as compulsory subject. The six sampled schools were made up of two (2) arms each that is A and B. The ' $\mathrm{A}$ ' arm was assigned to be taught with demonstration method, while arm ' $\mathrm{B}$ ' was to be taught with the conventional lecture method. The assignment of classes to treatment and control groups was through a simple random technique. In each of the groups and schools, one intact class was drawn for the study through a simple random sampling technique. There were altogether twelve (12) intact classes that was used for the study, six (6) for the treatment and six (6) for the control. A thirty-item Agricultural Science Achievement Test (ASAT) was constructed from five identified difficult topics/areas in the curriculum for SSII. The thirty-item multiple choice questions were made up of four options lettered A-D. The ASAT was divided into five sections (A-E) based on the five content areas to be covered. The areas were vegetative propagation in plants; knapsack sprayer; digestive system and reproductive system in birds; soil related experiments and genetics. The questions were to measure the students' achievement on the five major topics at SSII level. The ASAT was used for both pre-test and post-test. The ASAT constructed by the researcher was face and content validated by experts in Test and measurement and Agricultural Education. Kuder Richardson 20 (K-R20) was used to determine the internal consistency of the instrument. The ASAT yielded a reliability index of 0.78. A lesson plan each on the selected topics was prepared and used to teach the treatment and control groups by the selected trained agricultural science teachers in the sampled schools. The two groups were exposed to teaching for a period of two (2) mouths, one group using demonstration method with 240 students and the other using conventional lecture method with 240 students. The research questions and hypothesis were answered using mean and standard deviation and analysis of covariance (ANCOVA) at 0.05 level of significance.

\section{Research question 1}

Is there any significant difference in the mean achievement scores of students taught agricultural science using demonstration and conventional lecture methods?

Table 1: Relative Students' Mean Achievement Scores in Agricultural Science Achievement Test (ASAT) with Demonstration and Conventional Lecture Methods

\begin{tabular}{|c|c|c|c|c|}
\hline Group & Symbol & Pretest & Posttest & $\begin{array}{l}\text { Mean Gain } \\
\text { Difference }\end{array}$ \\
\hline Demonstration & $\underline{\mathrm{N}}$ & 240 & 240 & \\
\hline method & $\bar{X}$ & 47.77 & 66.57 & 18.82 \\
\hline $\begin{array}{l}\text { (Experimental } \\
\text { Method) }\end{array}$ & $\mathrm{SD}$ & 4.48 & 7.75 & \\
\hline Conventional & $\underline{\mathrm{N}}$ & 240 & 240 & \\
\hline Lecture Method & $\mathrm{X}$ & 46.33 & 61.47 & 15.14 \\
\hline (Control) & SD & 4.30 & 6.25 & \\
\hline
\end{tabular}

$\mathrm{N}=$ Number of Subjects; $\bar{X}=$ Mean and $\mathrm{SD}=$ Standard Deviation

Table 1 shows that prior to the use of demonstration method (experimental method) in the teaching of agricultural science by agricultural science teachers in the experimental group, the mean score was 47.77 while the standard deviation was 4.48. The control group has a pretest mean score of 46.33 and the standard deviation of 4.30 in the ASAT and this is lower them that of the experimental group. The standard deviation of 4.48 for the experimental group as against 4.30 for the control group showed that the range of scores between the experimental and control group was very narrow. But after the treatment which was teaching the students, the posttest mean scores for the 
experimental students improved appreciably from 47.77 to 66.57 while their standard deviation shows a decrease. But for the control group, it was an improvement from a mean score of 46.33 to 61.47 and an increase in standard deviation of 4.30 to 6.05 . But when compared with the experimental group, it was low. This shows that there is a slight closeness in the test scores. The table also shows that the mean gain difference was 18.82 for demonstration method and 15.14 in conventional lecture method. This implies that subject taught with demonstration method performed better in the achievement test than those taught with conventional lecture method. A moderate performance difference existed between the experimental and control group subjects.

\section{Research question 2}

What is the academic achievement scores of male and female students taught agricultural science with demonstration and conventional lecture method?

This research question was answered using the data collected and this is shown in table 2 below.

Table 2: Means Academic Achievement Scores of Male and Female Students Taught Agricultural Science with the Demonstration and the Conventional Lecture Methods

\begin{tabular}{|c|c|c|c|c|c|}
\hline Group & $\begin{array}{l}\text { Teaching } \\
\text { Method }\end{array}$ & Symbol & Pretest & Posttest & $\begin{array}{l}\text { Mean Gain } \\
\text { Difference }\end{array}$ \\
\hline \multirow[t]{3}{*}{ Male } & Demonstration & $\underline{\mathrm{N}}$ & 126 & 126 & \\
\hline & (Experimental & $\mathrm{X}$ & 47.52 & 70.30 & 22.78 \\
\hline & Method) & $\mathrm{SD}$ & 4.52 & 5.36 & \\
\hline \multirow[t]{3}{*}{ Female } & Demonstration & $\underline{\mathrm{N}}$ & 114 & 114 & \\
\hline & (Experimental & $\mathrm{X}$ & 48.04 & 62.44 & 14.40 \\
\hline & Method) & SD & 4.35 & 7.98 & \\
\hline \multirow[t]{3}{*}{ Male } & Conventional & $\underline{\mathrm{N}}$ & 128 & 128 & \\
\hline & Lecture & $\mathrm{X}$ & 45.55 & 64.37 & 18.82 \\
\hline & $\begin{array}{l}\text { Method } \\
\text { (Control) }\end{array}$ & SD & 3.58 & 4.27 & \\
\hline \multirow[t]{3}{*}{ Female } & Conventional & N & 112 & 112 & \\
\hline & Lecture & $\mathrm{X}$ & 47.23 & 58.17 & 10.94 \\
\hline & $\begin{array}{l}\text { Method } \\
\text { (Control) }\end{array}$ & $\mathrm{SD}$ & 4.87 & 6.53 & \\
\hline
\end{tabular}

$\mathrm{N}=$ Number of Subjects, $\overline{\mathrm{x}}=$ Mean, $\mathrm{SD}=$ Standard Deviation

Table 2 shows that the pretest means scores of students taught with the two methods of teaching i.e. demonstration (experimental method) and conventional lecture method (control) were found to be 47.52 and 45.55 for male and 48.04 and 47.23 for female respectively; while the post test results shows 70.30 and 64.37 for male and 62.44 and 58.17 for female respectively. These results show there is a difference between the students pretest and post-test scores in each method of teaching. The difference is highest with demonstration and lowest with the conventional lecture method. The mean gain differences are 22.98 for the demonstration method and 18.22 for the conventional lecture method; for the female students the mean gain scores are 14.40 and 10.94 in each method respectively.

The results further shows that the difference in posttest mean score is highest among male and female students taught with demonstration method and least by those taught with conventional lecture method. In the case of variability of test scores, the standard deviation obtained in each case showed a minimal spread of scores. It was also noticed that there was a little increase in the posttest mean scores for female students taught with demonstration and conventional lecture methods. 


\section{Hypothesis}

There is no significant difference in the Agricultural Science achievement scores between students taught with demonstration method and students taught with conventional lecture method.

Table 3: Analysis of Covariance of the Mean Achievement Scores of Students Taught Agricultural Science with Different Methods

\begin{tabular}{llllll}
\hline $\begin{array}{l}\text { Source of } \\
\text { Variance }\end{array}$ & Sum of squares & df & Mean square & F & Sig. Level at 0.05 \\
\hline $\begin{array}{l}\text { Demonstration and } \\
\text { conventional }\end{array}$ & & & & & \\
lecture method & & & & & \\
(DM \& CLM) & 14181.089 & 1 & 14181.089 & 273.73 & S. \\
Group (methods) & 4880.385 & 1 & 4880.385 & 133.992 & 3. \\
Pretest & 187.029 & 1 & 187.029 & 3.61 & NS \\
Error & 37094.151 & 476 & 51.807 & & \\
Total & 56242.654 & 479 & & & \\
\hline
\end{tabular}

Table 3 above shows that, the calendared F-ratio in each row is compared with the table F-ratio at 0.05 level of significance to find out if the hypothesis is accepted or not. The calculated F-ratio between demonstration method (experimental method) and conventional lecture method (control) was found to be 273.73 and the table F-value at df1, 476 at 0.05 level of significance was 24.4. Since the calculated F-ratio was greater than table F-value at df1, 476 at 0.05 level of significance, the stated null hypothesis is therefore rejected meaning there was significant difference between the mean achievement scores of students taught with demonstration method and conventional lecture method. Students taught with demonstration method recorded higher test mean scores than those taught with conventional lecture method.

\section{Findings of the Study}

Based on data analysis, the following findings were made:

1. Each of the two groups of teaching agricultural science recorded higher mean scores in the post-treatment test than in the pre-treatment test (Table 1).

2. Students taught agricultural science with demonstration method $(\overline{\mathrm{x}}=66.57)$ had the highest mean scores in the post-treatment mean scores than those taught with the conventional lecture method $(\bar{x}=61.47)$ (Table 1).

3. Male students taught with the demonstration method scored higher $(\bar{x}=70.30)$ than female students $(\mathrm{x}=$ 62.44) (Table 2).

4. Male students taught with the conventional lecture method scored higher $(\bar{x}=64.57)$ than female students $(\bar{x}=58.17)$.

5. Male students scored higher when taught with both demonstration method and conventional lecture method as compared to their female counterparts.

6. There was a significant difference $(\mathrm{P}<0.05)$ in the academic achievement scores of students separately taught agricultural science with the demonstration method and those with conventional lecture method.

\section{Discussion of Findings}

The students that were taught with the demonstration method were found to have high achievement scores in the ASAT than their counterparts in the control group that were taught with the conventional lecture method of teaching. This finding is in agreement with some earlier findings of Idoko and Oladimeji (2002) and Alio (1997). These researchers observed that the students in the experimental group who were allowed to interact and allowed to carry out activities in group performed better than those in the control group who were mere passive listeners in their agricultural classes. The demonstration method used in this study was activity oriented and encourage students - 
teachers, students - students and students - material interactions.

Students in the experimental group who recorded high achievement scores, was taught with the use of more activity oriented teaching method (Demonstration method). The activity nature of the teaching method made the students to provide relevant answers to the ASAT questions than their counterparts in the control group, that was not exposed to the activity - based method. This agrees with Musa (2007) who stated that adoption of good and thought provoking teaching methods, under conducive learning environment, facilitate better learning and mastery of the learnt materials by students.

The results showed that male and female students taught under the experimental group (Demonstration method) performed better than those in the control group (conventional lecture method). Male students taught agricultural science with DM $(\bar{x}=70.30)$ and CLM $(x=64.37)$ performed better in the ASAT than female students taught the same subject using the same methods DM $(\overline{\mathrm{x}}=62.44)$ and CLM $(\overline{\mathrm{x}}=58.17)$. Comparing the two methods, male students performed higher than their female counterparts. This agrees with Virpi, Kirsti and Sari (2004); Daluba \& Audu (2005) and Adenyika \& Mutula (2006). These researchers observed that difference existed between the performance of male and female students in the science and other science related courses like agricultural science. They added they performances were better with male group. Also, it is evident from the findings of this present study that male students performed better in the ASAT than their female counterparts. This agrees with the findings from the study by Daluba \& Audu (2005) when they both found out that male students (75.5\%) performed better in agricultural science than their female $(60.19 \%)$ counterparts. The reason deduced from the disparity was that agricultural science is practical and skill oriented course which is more inclined to males than females because of their femine nature as group of people in the society. Male students taught with the demonstration method performed better than the female group. This therefore implies that demonstration method increase students interest and understanding and consequently promoting high achievement rate.

The results of hypothesis revealed that the mean achievement scores of the different groups of students taught with the different teaching methods - DM and CLM differed significantly. The test scores recorded by students depend greatly on the teaching method(s) employed by the agricultural science teachers. This therefore agrees with Ajewole (1990); Nzewi \& Osisioma (1994), Ibitoye (2006); Eilks (2002); Pekene (2002) \& Mundi (2006), when he found out that the performance recorded by students in agricultural science lesson is solely dependent on the attractive and stimulating nature of the method(s) employed by the teachers of agriculture.

\section{Conclusion and Recommendations}

Conclusively, secondary school students performed differently when taught with the demonstration and conventional lecture methods. Students' performance in the conventional lecture group is lower than those in the experimental group (demonstration method) as they learnt the selected concepts with difficulty. Male students pronouncedly performed better than their female counterparts when taught with both the experimental and control methods. Finally, there was a significant difference in the academic achievement scores of students separately taught agricultural science with the demonstration and conventional lecture methods.

Based on the findings and conclusion of the study, the following recommendations were proffered:

1. Secondary school teachers should be discouraged from the continuous use of conventional lecture method in the teaching of agricultural science as the method make students performed poorly in the ASAT tasks in agricultural science.

2. Attention should be adequately paid to the female folds by advising teachers of agricultural science to effectively employ the use of demonstration method in a way that it will help improve female students performance in agricultural science. This is because the result of the study have shown a significant difference in their mean achievement scores in favor of males,

3. The findings of the study revealed that significant differences existed in the mean achievement scores in favour of the students taught agricultural science using demonstration method as opposed to those taught with the conventional lecture method. This requires teachers to make efforts to integrate thoroughly demonstration method into the teaching of agricultural science in secondary schools.

4. Text-book authors should consider it as a priority, to include in their texts, the effective use and application of demonstration method in the teaching and learning of agricultural science so that the teachers and learners should apply them when the need arises. 
5. Finally, government and professional bodies should further research on the effectiveness of demonstration method in other aspects of agricultural science. Similarly, such professional bodies should organize conferences, workshops and seminars on the importance of teaching and learning approaches like the demonstration method and all technicalities involved in the method as a way of widening the horizons of teachers.

\section{References}

Adah, O. C. (2011). An assessment of students' perception of agricultural science as a course of study in secondary schools in Kogi State. Journal of Vocational and Technical Educators, 2(1), 14-19.

Adeyinka, T., \& Mutula, S. M. (2006). Gender differences in computer literacy among undergraduate students at the University of Botswana: Implication for library Use. Retrieved October 23, 2008, from http/myais.fsktm.un.educ.my/23631

Ajewole, G. O. (1990). Effects of Guided Discovery and Expository Instructional Methods on Students Transfer of Learning. Journal of Science Teachers' Association of Nigeria (JSTAN), 26(2), 59-66.

Alio, B. C. (1997). Polya's problem solving strategy in secondary school students' achievement and interest in Mathematics. An unpublished PhD Thesis. Faculty of Educaiton, Nsukka: University of Nigeria.

Ameh, I-Ei, Daniel, B. P., \& Akus, Y. (2007). Research and Methods in the Social Sciences. Ankpa: Rowis press.

Daluba, N. E., \& Audu, T. A. (2005). Comparing the Academic Performance of Sandwich and Regular Students in science, Technology and Mathematics Education (STME). Implications for standards. Sandwish/Part-Time Programme and Science, Technology and Mathematics Education in Nigeria (Omonu, J. B.; Audu, T. A. \& Agashi, P. P. eds). Ankpa.

Egun, A. C. (2007). Reducing Teacher's Instructional Differentials in Identified content area of Agricultural Science syllabus of Senior Secondary School for Better Understanding in Nigeria. Journal of Social Sciences, 15(2), 141-145.

Eilks, I. (2002). "Learning at stations' in secondary level chemistry lessons. Science Education International, 12(1), 11-18.

Federal Republic of Nigeria (2009). National Policy on Education. Lagos: NERDC Press.

Ibitoye, S. J. (2006). The effects of Gender differences on students' Achievement in Agricultural Science in Some Selected Senior Secondary Schools in Kogi East Senatorial District of Kogi State. Ankpa: Teacher Education Journal (TEJ), 10(1), 40-46.

Idodo, C. U., \& Oladimeji, A. J. (2002). Agricultural Improvement and Development through Education. An overview. Teacher Education Journal, 2(1), 35-40.

Mundi, N. E. (2006). The state of students' academic achievement in secondary school agricultural science in Kogi State. Teacher Education Journal (TEJ), 12(1), 14-19.

Musa, S. A. A. (2007). The effect of lecture method on students' achievement in physics in secondary schools in Kogi State. Journal of Vocational and technical Educators (JOVOTED), 1(1), 12-17.

Nzewi, U. M., \& Osisioma, N. (1994). The relationship between formal reasoning ability, acquisition of process skills and science achievements. Journal of Science Teachers' Association of Nigeria, 29(1\&2), 41-45.

Olaitan, S. O. (1984). Agricultural Education in the Tropics - Methodology for Teaching Agriculture. London: Macmillan Publishers.

Pekene, D. J. (2002). Effects of Greeno and Mettes et al Problems Solving Models on Students Achievement in Physics. Journal of Science Teachers'Association of Nigeria (STAN), 37(1\&2), 39-43.

Virpir, S., Kirsti, L., \& Sari, L. (2004). Study strategy used in learning from text: Does gender make any difference? Retrieved July 112008 from http//www.springerlin.comm/content/kov724g9g81p48271 